\title{
PREDIKSI PEMBENTUKAN DAN KUALITAS AIR PIT LAKE: BERDASARKAN KONDISI HIDROLGI DAN GEOKIMIA BATUAN
}

\author{
Ginting J Kusuma ${ }^{1}$, Kris Pranoto ${ }^{2}$, Gindang R Pratama ${ }^{1}$, Edy J Tuheteru ${ }^{1,3}$ Imanuel Manege \\ dan Rudy S Gautama \\ ${ }^{1}$ Kelompok Keilmuan Pengelolaan Lingkungan Tambang, Fakultas Teknik Pertambangan dan Perminyakan, \\ Institut Teknologi Bandung, Bandung. \\ ${ }^{2}$ Departemen Lingkungan, PT. Kaltim Prima Coal, Kalimantan Timur. \\ ${ }^{3}$ Program Studi Teknik Pertambangan, Universitas Trisakti, Jakarta.
}

\begin{abstract}
ABSTRAK
Pada akhir masa penambangan, tambang batubara terbuka akan membentuk kolam tambang (pit lake) yang kualitas air bentukannya dipengaruhi oleh kualitas air lindian tiap litologi batuan dinding pit. Lokasi penelitian dilakukan di salah satu pit di wilayah Kalimantan, dengan litologi batuan dinding pit terdiri dari $30 \%$ batuan yang berpotensi asam dan $70 \%$ batuan yang tidak berpotensi asam dengan kualitas air sump memiliki $\mathrm{pH}$ yang rendah. Penilitian ini dilakukan untuk membuat prediksi pengisian pit dengan air dan waktu yang dibutuhkan sampai pit terisi dengan air secara penuh selain itu juga dilakukan prediksi kualitas air yang akan terbentuk. Berdasarkan data hidrologi yang ada, maka pit pada lokasi penelitian diprediksi akan terisi penuh dan mencapai permukaan air yang stabil pada tahun ke-36 dengan total volume air $24.000 .000 \mathrm{~m}^{3}$, sumber air utama yang digunakan untuk menghitung lama waktu terisi air adalah air hujan yang jatuh langsung ke dalam pit, tanpa memperhitungkan luasan tangkapan hujan di sekitar pit. Prediksi kualitas air pada pit lake dilakukan dengan pencampuran (mixing) air lindian pada tiap litologi dinding pit menggunakan perangkat lunak PHREEQC dengan data karakteristik geokimia, kualitas air lindian sampel, dan kandungan mineral pada batuan, berdasarkan data tersebut, maka dilakukan prediksi kualitas air dengan menggunakan tiga skenario yakni skenario optimis, konservatif dan proporsional. Hasil yang diperoleh pada prediksi kualitas air terutama untuk nilai $\mathrm{pH}$ yang akan terbentuk di tahun ke-36 adalah sebagai berikut skenario optimis sebesar 6,8, skenario konservatif sebesar 3,13 dan skenario proporsional adalah sebesar 3,42.
\end{abstract}

Kata Kunci : Air lindian, kualitas air, simulasi prediksi, pit lake

\section{A. PENDAHULUAN}

Pit lake terbentuk setelah kegiatan pertambangan berakhir dan tidak dilakukan pengisian atau pengisian sebagian pit bekas penambangan dengan batuan penutup [1]. Setelah penambangan berakhir, sumur pompa dimatikan, yang memungkinkan muka air naik kembali dan memungkinkan air membanjiri lubang seiring waktu. Bergantung pada volume pit dan laju tahunan debit air tanah dan pengalihan air permukaan ke dalam pit, diperlukan waktu antara 1 tahun hingga 500 tahun untuk mencapai tingkat terpenuhinya air di pit lake dalam kondisi stabil [2]. Air yang memenuhi pit lake bersumber dari air tanah yang mengisi pit lake secara perlahan dan air permukaan alamiah yang masuk ke dalam pit atau air yang bersumber dari air dari tambang di sekitarnya, air laut maupun air permukaan [3].

Pemahaman konseptual tentang pit lake dapat digambarkan seperti proses yang terlihat pada Gambar I.2 (Castendyk dan Eary 2009), yang dibangun sesuai dengan aspek hidrologi, geologi, dan limnologi yang saling terkait. Pada bagian bawah bangan alir tersebut aspek yang paling utama adalah karakteristik batuan, geologi, iklim, dan hidrologi di area tambang. Aspek geologi dan 
karakteristik batuan berpengaruh terhadap bentuk akhir pit atau geometri pit, sedangkan untuk aspek hidrologi dan iklim berpengaruh terhadap kesetimbangan air pada pit. Hubungan antara geometri pit dan kesetimbangan air membentuk pit lake.

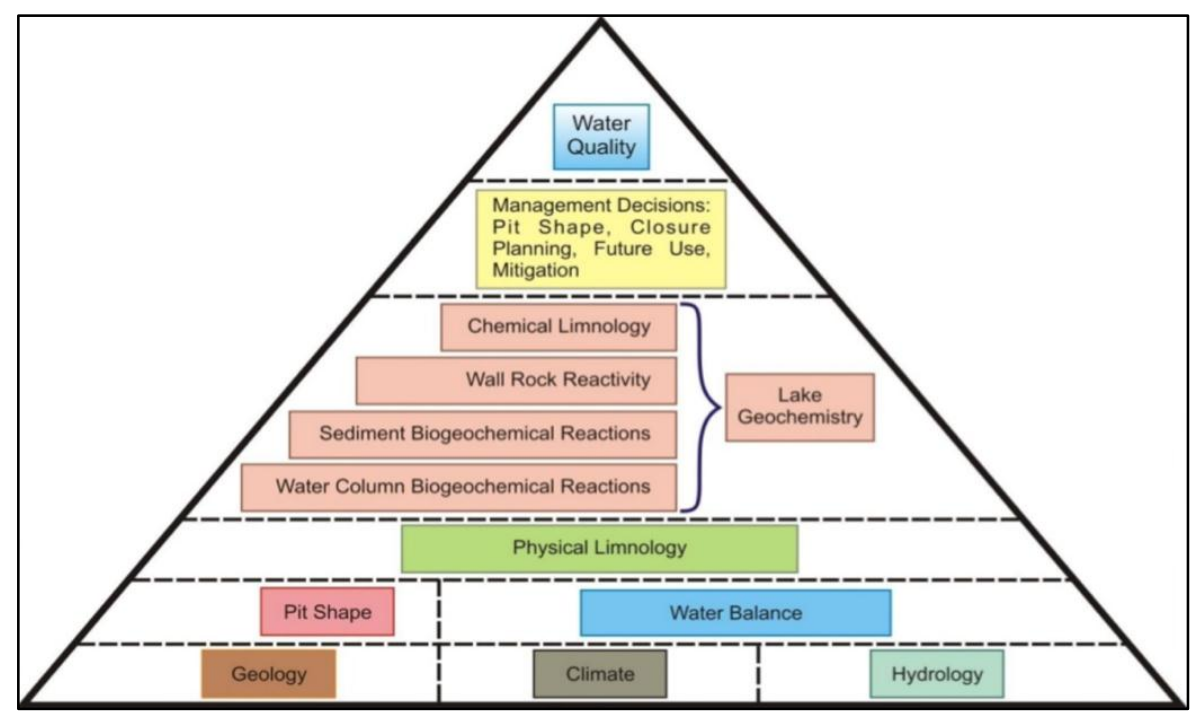

Gambar I.2 Faktor-faktor yang berpengaruh terhadap kualitas air pit lake

Reaksi air dengan batuan dan proses kimia yang terjadi di dinding lubang pit baik di atas maupun di bawah permukaan air, di dalam kolom air, dan di dalam sedimen yang ada di dasar pit, prosesproses ini penting untuk mempengaruhi keseimbangan asam-basa air dan laju pelepasan logam dari oksidasi mineral logam sulfida yang membentuk kondisi kima pada pit lake. Komposisi kualitas air di pit lake adalah produk dari kombinasi semua proses yang ada pada bagan alir tersebut.

Model konseptual dan prediksi kualitas air jangka panjang di pit lake akan meningkat tingkat kepercayaannya seiring semakin banyak data yang tersedia yang sejalan dengan berlangsungnya siklus penambangan. Prediksi model dapat memberikan masukan kepada regulator, pemilik tambang, dan pemangku kepentingan lainnya dengan memberikan informasi penting untuk mengantisipasi dan mengatasi masalah kualitas air yang akan timbul setelah kegiatan pertambangan dihentikan (Dunbar dalam Geller, 2013).

Saat akhir masa penambangan, litologi batuan yang terekspos pada dinding pit akan mempengaruhi kualitas air yang terbentuk pada pit lake. Pembentukan kualitas air pada pit lake dapat dianalisis dengan menggunakan metode inverse modelling menggunakan software PHREEQC [4]. Setelah mendapatkan kualitas air dan mineral yang bereaksi pada tiap litologi batuan di pit, dapat dilakukan prediksi kualitas air yang akan terbentuk pada pit lake dengan mencampurkan kualitas air dari tiap litologi (mixing), prediksi ini dilakukan dengan berbagai skenario pencampuran litologi batuan pada pit berdasarkan karakterisasi geokimianya.

Dengan demikian penilitian ini dilakukan untuk mendapatkan metode dalam melakukan prediksi kualitas air pit lake dengan melakukan beberapa skenario yang dipengaruhi oleh faktor hidrologi dan geokimia batuan.

\section{B. METODOLOGI}

\section{B.1. Daerah penelitian}

Daerah penelitian ini berada pada salah satu pit penambangan batubara di wilayah Kalimantan, Indonesia. Peta desain akhir dipadukan dengan lokasi pengambilan sampel batuan dinding pit. Pada 
lokasi penelitian terdapat 3 lapisan yang mendominasi pada litologi di daerah penelitian, yaitu batulempung, batupasir, dan batubara (Gambar 1).

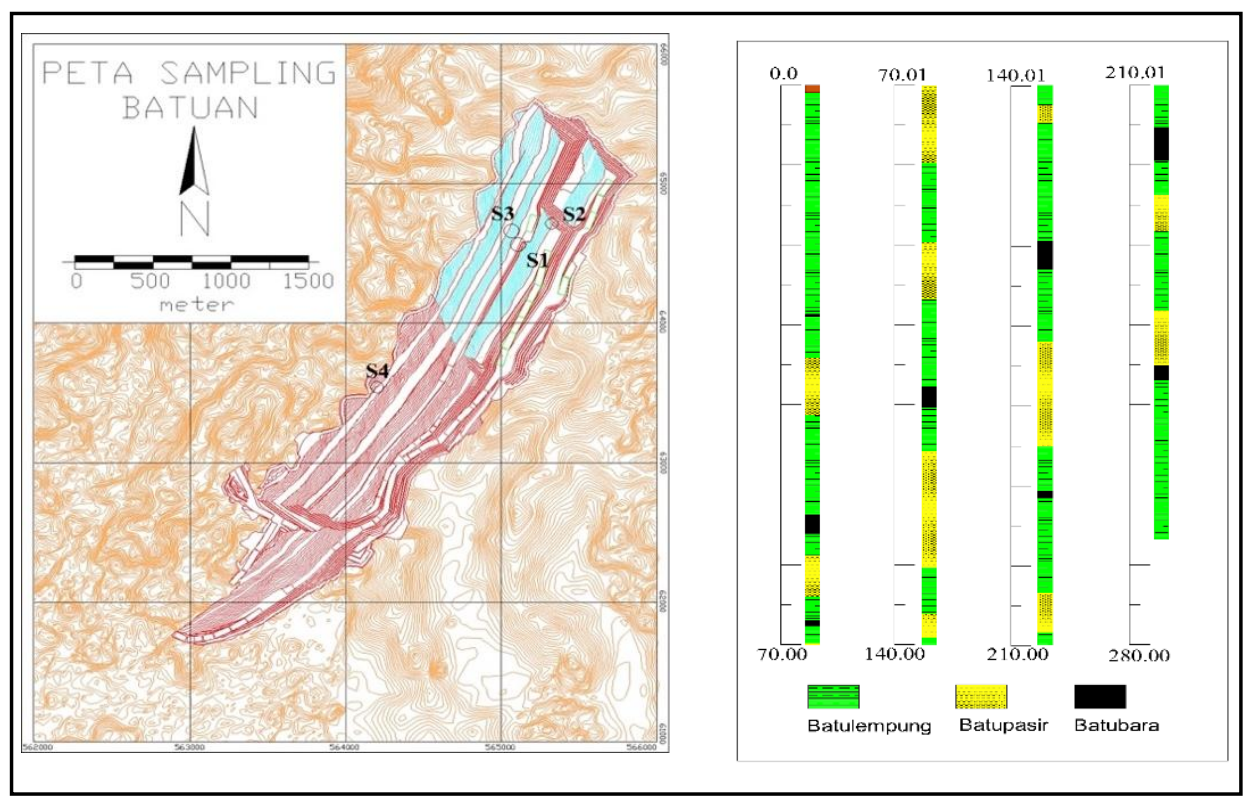

Gambar 1. Bentuk pit dan litologi batuan daerah penelitian

\section{B.2. Pengambilan Sampel}

Sampel batuan pada penelitian ini diambil pada salah satu pit di daerah Kalimantan. Jumlah sampel yang digunakan dalam penelitian ini adalah 4 sampel, yaitu sampel S1, S2, S3, dan S4. Sampel yang diambil mewakili litologi yang ada pada lokasi penambangan. Lokasi pengambilan sampel juga ditetapkan berdasarkan faktor keamanan pengambilan sampel. Didapatkan pula data ketinggian sampel yaitu sampel S4 yang berada pada ketinggian 50 meter di atas permukaan laut, sampel S3 berada pada ketinggian 25 meter di atas permukaan laut, sampel S1 berada pada -10 meter di bawah permukaan laut dan sampel S2 berada pada -20 meter di bawah permukaan laut. Selain mendapatkan data litologi dan bentuk pit, diperoleh juga data iklim pada wilayah pertambangan berdasarkan data pengukuran iklim dan curah hujan pada stasiun pengukuran di wilayah pertambangan, data yang diperoleh adalah data curah hujan harian dari tahun 1985 hingga tahun 2017, untuk memperoleh data kualitas air, dilakukan pengambilan sampel air di sump dan air hujan.

\section{HASIL PENELITIAN}

\section{C.1. Hasil Uji Statik dan Uji Kinetik}

Hasil uji statik menunjukkan bahwa nilai $\mathrm{pH}$ pasta untuk setiap sampel adalah $\mathrm{S} 1$ dengan nilai 4,63, S2 dengan nilai 5,89, S3 dengan nilai 2,72 dan S4 dengan nilai 5,89, sementara nilai ANC hanya terdapat pada dua sampel yakni sampel S2 dan S4 dengan masing-masing sebesar 3,36 kg $\mathrm{H} 2 \mathrm{SO} 4 /$ ton dan 3,83 $\mathrm{kg} \mathrm{H} 2 \mathrm{SO} 4 /$ ton sementara nilai total sulfur terbesar dimiliki oleh sampel S2 dengan nilai sebesar $1,45 \%$ dan terendah dimiliki oleh sampel S1 dengan nilai sebesar 0,59\%. Klasifikasi geokimia bauan dilakukan berdasarkan nilai pH NAG dan NAPP tiap sampel batuan, dimana saat NAPP $>0$ dan $\mathrm{pH}$ NAG $<4,5$ diklasifikasikan sebagai PAF, NAPP $<0$ dan pH NAG $>$ 4,5 diklasifikasikan sebagai NAF, dan selain dari itu diklasifikasikan sebagai UC. Berdasarkan hasil karakterisasi geokimia batuan diperoleh semua sampel batuan tergolong tipe Potential Acid Forming (PAF), seperti terlihat pada Tabel 1. 
Tabel 1. Kriteria Penapisan Untuk Klasifikasi Geokimia Batuan

\begin{tabular}{|c|c|c|c|c|c|}
\hline \multirow{2}{*}{ Sampel } & \multirow{2}{*}{ NAG pH } & \multicolumn{2}{|c|}{ NAG $\left(\mathrm{Kg} \mathrm{H}_{2} \mathrm{SO}_{4} /\right.$ ton $)$} & \multirow{2}{*}{ NAPP } & \multirow{2}{*}{$\begin{array}{c}\text { TIPE } \\
\text { BATUAN }\end{array}$} \\
\hline & & $\mathrm{pH} 4.5$ & 18,14 & & \\
\hline S1 & 2.45 & 56.8 & 41,06 & 0.59 & PAF \\
\hline $\mathrm{S} 2$ & 2.62 & 24.00 & 27,46 & 1.45 & PAF \\
\hline S3 & 2.60 & 31.00 & 14,90 & 0.90 & PAF \\
\hline S4 & 3.11 & 5.67 & NAPP & 0.61 & PAF \\
\hline
\end{tabular}

Berdasarkan hasil uji kinetic, pada siklus harian, nilai pH sampel S1 mengalami kenaikan dari 5,49 pada hari pertama hingga 6,05 pada hari ke-28. Nilai pH pada sampel S2 menurun dari 7,13 pada hari pertama menjadi 6,62 pada hari ke-28. Nilai pH sampel S3 mengalami penurunan dari 2,58 pada hari pertama menjadi 2,36 pada hari ke-28. Nilai pH sampel S4 mengalami kenaikan dari 5,69 pada hari pertama menjadi 6,28 pada hari ke-28 (Gambar 3).

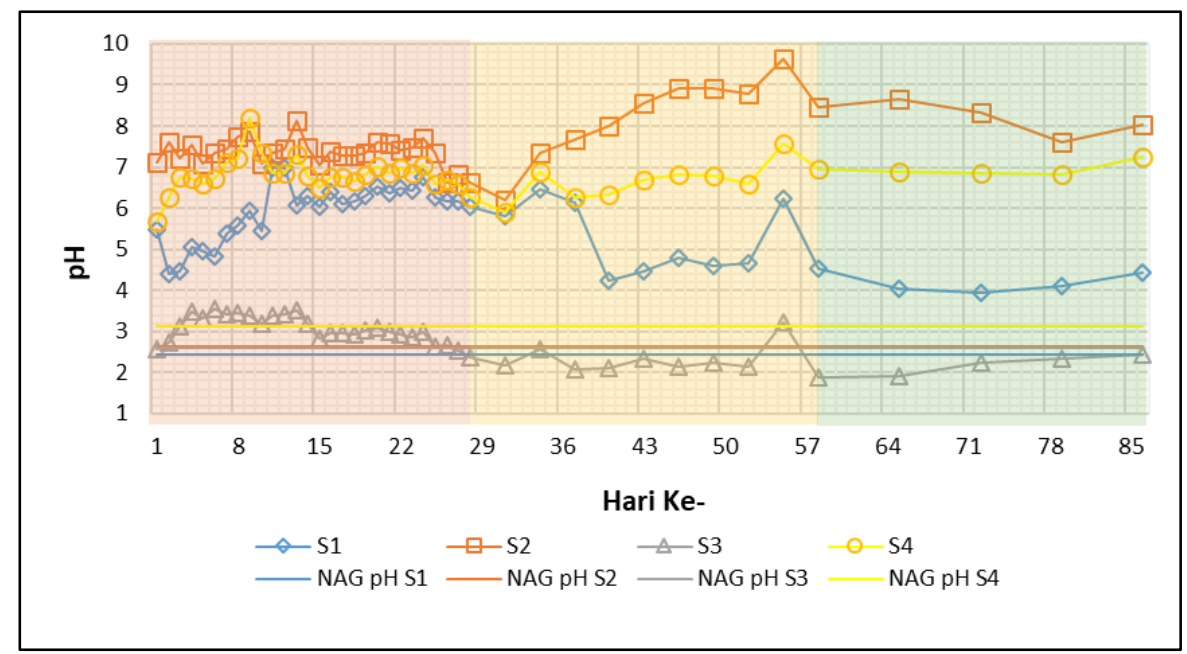

Gambar 3. Grafik Nilai pH Hasil Uji Kinetik Sampel Batuan Dinding Pit

Setelah memperoleh hasil uji statik dan uji kinetik pada sampel tersebut, maka dominasi distribusi batuan di lapangan didominasi oleh batuan yang bersifat Potentially Acid Forming (PAF)

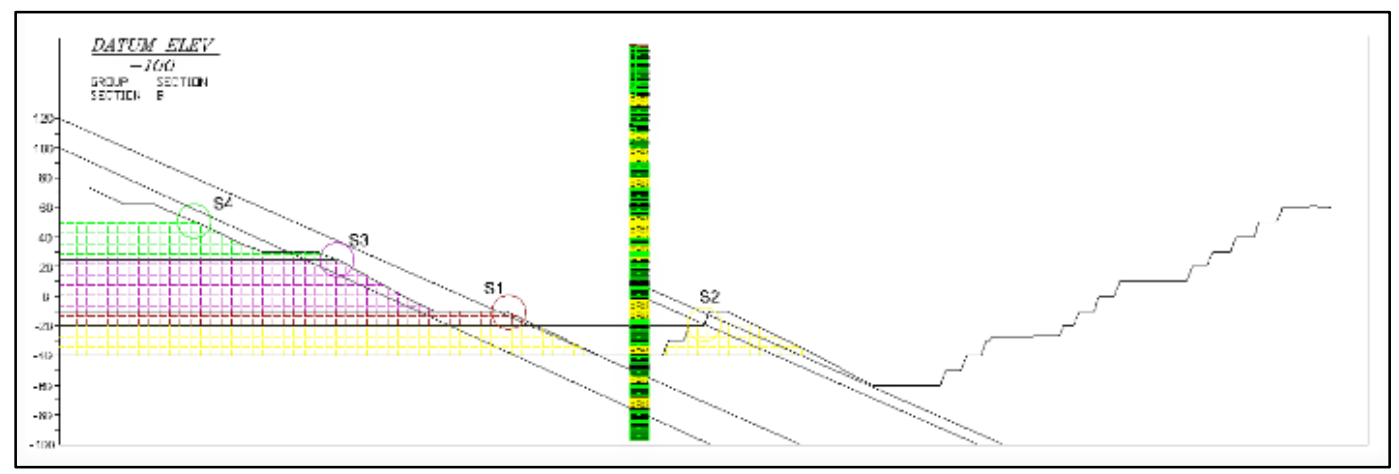

Gambar 2. Litologi Persebaran Sampel Batuan Dinding Pit

\section{C.2. Hasil Uji XRD dan XRF}

Berdasarkan hasil uji XRD, diperoleh semua sampel mengandung silika dan kaolinit, mineral pirit terdapat pada sampel S1, S2 dan S3, untuk mineral hematite hanya terkandung di sampel S2 dan S3 sedangkan mineral montmorillonite hanya berada di sampel S3 dan kalsit hanya berada di sampel S4. Hasil uji XRF menujukkan bahwa pada unsur $\mathrm{SiO} 2$ mendominasi terutama untuk sampel S1, 
S2 dan S3 dengan kandungan masing-masing sebesar 65,4\%, 63,8\% dan 63,8\%, sedangkan untuk sampel S4 didominasi oleh unsur Fe2O dengan kandungan sebasar 40,5\%.

\section{C.3. Kualitas Air Hujan dan Air Sump}

Dari data pengukuran kualitas air yang dilakukan langsung di tiga lokasi sump dengan kode sampel PSML1, PSML2 dan PSJR yang ada di lokasi penelitian. Berdasarkan hasil pengukuran diperoleh kualitas air untuk ketiga lokasi bersifat asam, dimana untuk masing-masing sump adalah PSML1 dengan nilai $\mathrm{pH}$ antara 2,84-2,85, untuk PSML2 dengan nilai $\mathrm{pH}$ sebesar 2,84 hingga 2,88 dan lokasi PSJR memiliki nilai pH sebsar 3,00 - 3,06. Berdasarkan data tersebut maka kecenderungan kualitas air pada daerah penelitian akan bersifat asam.

Untuk kandungan logam pada masing sampel air yang diambil dari lapangan diperoleh bahwa kandungan Mg mendominasi masing sampel yakni untuk sampel PSML1 sebesar 168,03 ppm, sampel PSML2 sebesar 218,82 ppm dan untuk sampel PSJR sebanyak 264,22 ppm sama jumlahnya dengan kandungan logam $\mathrm{Ca}$. Sementara untuk kandungan Fe dan Mn pada masing-masing sampel adalah untuk kandungan Fe, sampel PSML1 sebanyak 63,79 ppm, sampel PSML2 sebanyak 20,91 ppm dan PSJR sebanyak 4,94 ppm, sementara untuk kandungan Mn, sampel PSML1 sebanyak 7,39 ppm, PSML2 sebanyak 8,60 dan sampel PSJR sebanyak 12,81.

Air hujan di lapangan juga diambil sempelnya dan dilakukan pengukuran dan pengujian kualitas air terutama untuk kandungan kimia, berdasarkan hasil pengukuran diperoleh bahwa kandungan sulfat $\left(\mathrm{SO}_{4}{ }^{2-}\right)$ adalah yang paling besar yakni $11,51 \mathrm{ppm}$ sedangkan kandung kimia yang terendah adalah alumunium yakni sebesar 0,02 ppm, sementara untuk nilai pH Air hujan adalah 6,8.

\section{ANALISIS DAN PEMBAHASAN}

\section{D.1. Prediksi pengisian pit dengan air}

Daerah penelitian dan sekitarnya beriklim tropis dengan curah hujan tahunan rata-rata selama periode tahun 1985-2017 adalah $2.168 \mathrm{~mm}$, pada periode tersebut curah hujan tahunan tertinggi terjadi pada tahun 2005 dengan curah hujan sebesar $2.993 \mathrm{~mm}$ dan curah tahunan terendah terjadi di tahun 2002 dengan curah hujan sebesar $1.549 \mathrm{~mm}$ (Gambar 4).

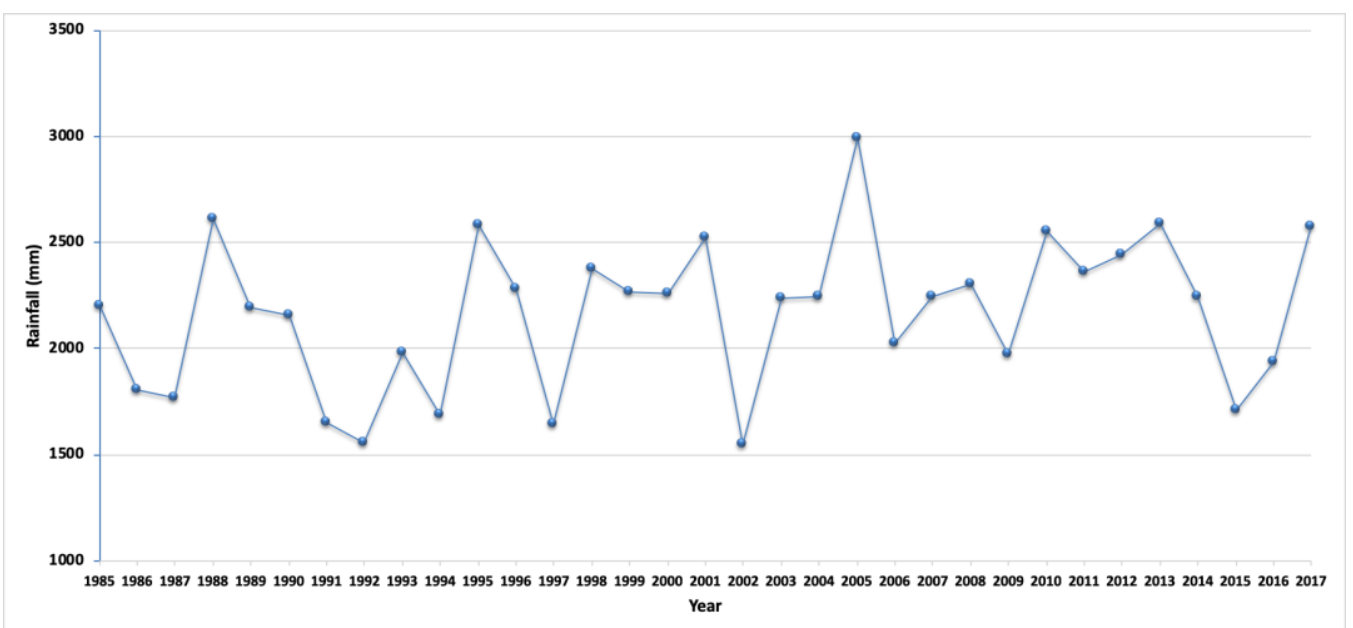

Gambar 4. Grafik Curah Hujan Tahunan wilayah penelitian (1985-2017)

Luas area yang diwakili oleh sampel S4 sebesar $14 \mathrm{Ha}$, sampel S3 mewakili area $21 \mathrm{Ha}$, sampel S1 mewakili $17 \mathrm{Ha}$, sedangkan sampel S2 mewakili 19 Ha. Total luas permukaan yang diwakili oleh semua sampel adalah $71 \mathrm{Ha}$. Pada panel 1 pit atau wilayah selatan, telah dilakukan in pit dumping, sehingga model yang nantinya akan digunakan sebagai pit lake adalah panel 2 dan 3 dari pit mengarah ke utara. Kedalaman maksimal pit pada elevasi -60 meter atau 60 meter di bawah 
permukaan laut. Pit akan penuh dengan air pada elevasi 10 meter di atas permukaan laut. Artinya, kedalaman pit yang akan terisi penuh oleh air adalah 70 meter (Gambar 5).

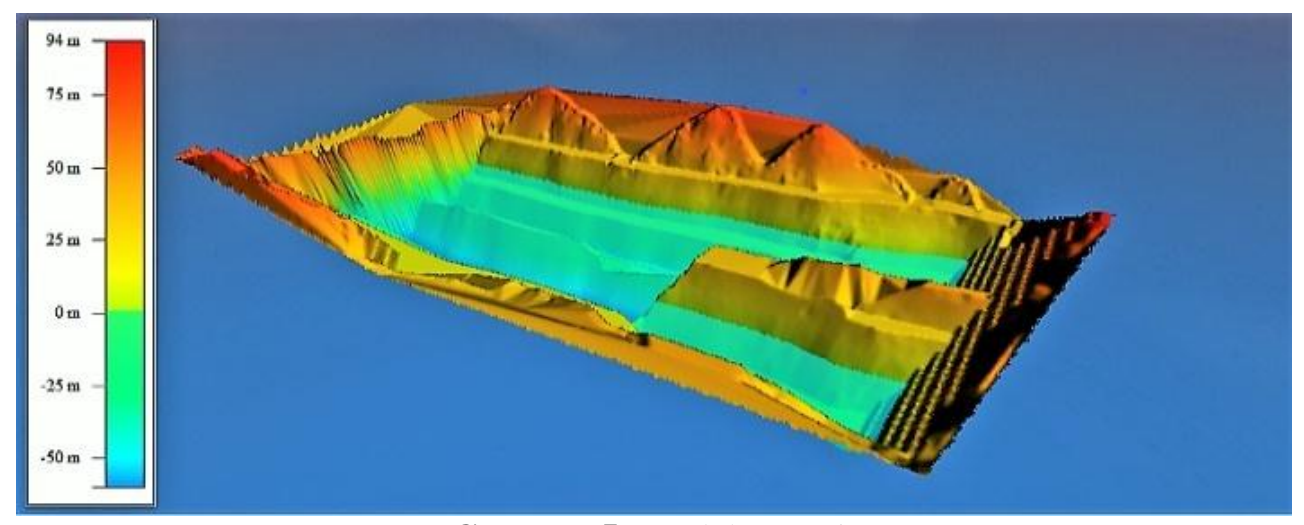

Gambar 5. Model 3-D Pit

Volume air akan terisi penuh jika mencapai 24.000.000 $\mathrm{m}^{3}$ (Gambar 6). Hujan yang masuk per tahun dengan menggunakan curah hujan bulanan rata-rata adalah $2.167 \mathrm{~mm}$, evaporasi per tahunnya adalah $1.080 \mathrm{~mm}$ dan koefisien limpasan sebesar 0,9, maka dapat dihitung jumlah presipitasi yang masuk ke dalam pit setiap tahunnya yaitu sebesar $700.000 \mathrm{~m}^{3}$. Dengan demikian, dibutuhkan waktu 36 tahun agar pit lake terisi air secara penuh. Perhitungan pengisian waktu yang dibutuhkan untuk pit terisi secara penuh hanya menggunakan data curah hujan yang langsung masuk dan potensi evaporasi yang terjadi di pit, artinya bahwa perhitungan tersebut belum mempertimbangkan luas area tangkapan hujan yang ada di sekitar pit. Jika area tangkapan hujan menjadi salah satu faktor yang dijadikan sebagai perhitungan lama waktu pengisian pit, maka lama waktu yang dibutuhkan untuk pengisian pit dengan air sampai penuh dan mencapai kondisi stabil akan berkurang.

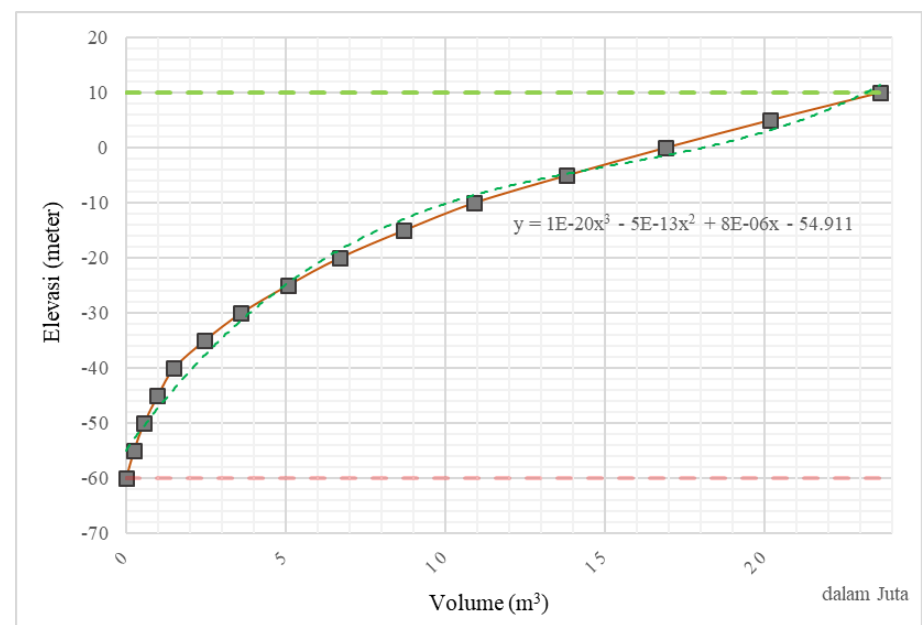

Gambar 6. Grafik Volume dan Ketinggian Air di dalam Pit

\section{D.2. Simulasi Prediksi Kualitas Air Pit Lake}

Simulasi prediksi kualitas air di pit lake ini akan dilakukan menggunakan metode mixing dengan fraksi pencampuran berdasarkan volume dan luas permukaan dari masing-masing litologi yang diwakili oleh sampel. Dalam simulasi ini digunakan tiga skenario pencampuran, yakni skenario optimis, skenario konservatif dan skenario proporsional. Skenario optimis merupakan skenario dimana litologi batuan dinding pit pada pit lake diwakili oleh sampel yang memiliki $\mathrm{pH}$ paling tinggi yaitu sampel S1, sedangkan skenario konservatif diwakili oleh sampel yang memiliki $\mathrm{pH}$ paling rendah yaitu sampel S3. Pada skenario proporsional, litologi batuan dinding pit pada pit lake 
menggunakan semua sampel yang mewakili litologi masing-masing sampel berdasarkan luas permukaannya. Di dalam skenario pencampuran, hal yang perlu diperhatikan adalah fraksi pencampuran atau perbandingan jumlah antar volume. Kondisi skenario pencampuran dilakukan dengan mengasumsikan pit lake dalam keadaan tidak terisi air, artinya belum ada air di dalam bekas pit penambangan.

\section{i. $\quad$ Skenario Optimis}

Skenario ini menggunkan sampel S1 sebagai perwakilan semua litologi dinding pit karena mempunyai nilai $\mathrm{pH}$ yang paling tinggi. Skema pencampuran sampel yang pertama melibatkan air lindian dari hasil metode forward modelling antara sampel S1 dengan air hujan. Kemudian akan dilakukan pencampuran dengan kualitas air hujan dengan fraksi perbandingan luas area. Hasil dari pencampuran ini kemudian menjadi kualitas air eksisting pada tahun pertama. Sedangkan tahun selanjutnya akan dilakukan pencampuran kembali terhadap air eksisting pada tahun sebelumnya dengan fraksi perbandingan volume sehingga akan menghasilkan kualitas air baru, skema ini dilakukan hinga pit lake terisi penuh (Gambar 7).

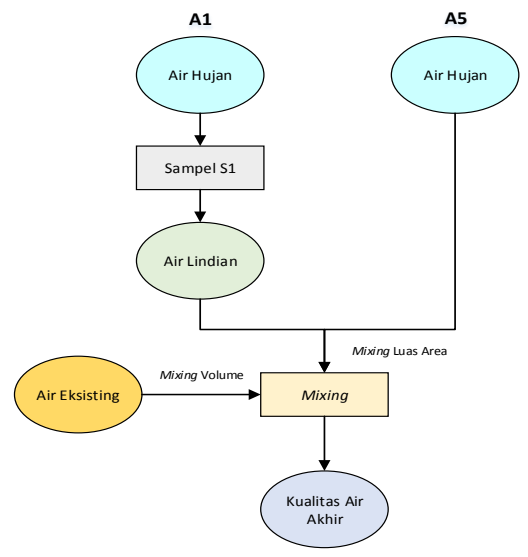

Gambar 7. Skema Pencampuran Skenario Optimis

Nilai $\mathrm{pH}$ pada skenario optimis mengalami kenaikan dari tahun pertama hingga tahun ke-16, yakni dari semula 6,75 hingga 6,8. Setelah tahun ke-16 hingga tahun ke-36, nilai pH konstan diangka 6,8. Nilai transfer mol Al mengalami penurunan dari $5,08.10^{-6}$ di tahun pertama sampai $2,5.10^{-6}$ di tahun ke-36. Nilai transfer mol $\mathrm{Fe}(2)$ mengalami kenaikan dari $2,79.10^{-7}$ di tahun pertama sampai $5,87.10^{-7}$ di tahun ke-36. Nilai transfer mol $\operatorname{Mn}(2)$ yaitu $1,8.10^{-7}$ dan konstan sampai tahun ke-36 (Gambar 8).

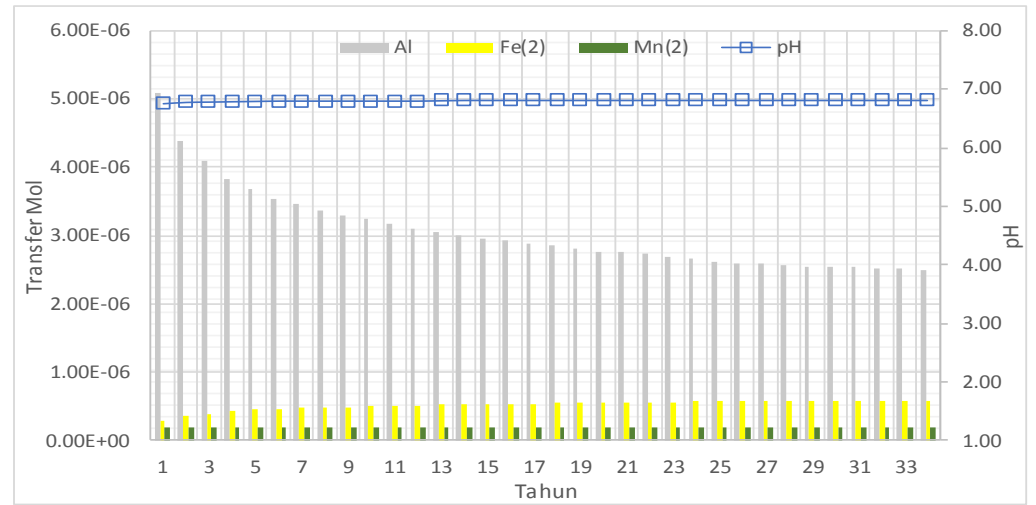

Gambar 8. Grafik Nilai pH, Al, Fe(2), dan Mn(2) pada Skenario Optimis Awal

\section{ii. Skenario Konservatif}

Skenario konservatif menggunkan sampel S3 sebagai perwakilan semua litologi dinding pit karena mempunyai nilai $\mathrm{pH}$ yang paling rendah. Skema pencampuran sampel yang pertama melibatkan air 
lindian dari hasil metode forward modelling antara sampel S3 dengan air hujan. Kemudian akan dilakukan pencampuran dengan kualitas air hujan dengan fraksi perbandingan luas area. Hasil dari pencampuran ini kemudian menjadi kualitas air eksisting pada tahun pertama. Sedangkan tahun selanjutnya akan dilakukan pencampuran kembali terhadap air eksisting pada tahun sebelumnya dengan fraksi perbandingan volume sehingga akan menghasilkan kualitas air baru. Skema ini dilakukan hinga pit lake terisi penuh (Gambar 9).

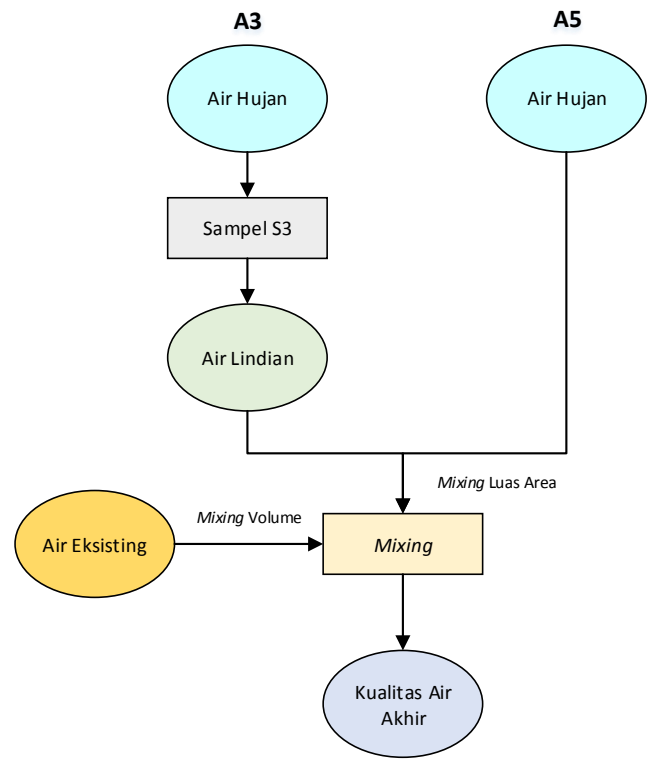

Gambar 9. Skema Pencampuran Skenario Konservatif

Pada skenario konservatif diperoleh Nilai $\mathrm{pH}$ di tahun pertama mengalami kenaikan hingga tahun ke-36, yakni dari semula 2,85 hingga 3,13. Nilai transfer mol $\mathrm{Fe}(2)$ mengalami penurunan dari $9,28.10^{-6}$ di tahun pertama sampai $4,12.10^{-6}$ di tahun ke-36. Nilai transfer mol Al menurun dari tahun pertama $3,12.10^{-6}$ sampai $1,68.10^{-6}$ di tahun ke-36. Nilai transfer mol $\operatorname{Mn}(2)$ mengalami kenaikan dari $1,57 \cdot 10^{-7}$ di tahun pertama sampai $1,74.10^{-7}$ di tahun ke-36 (Gambar 10).

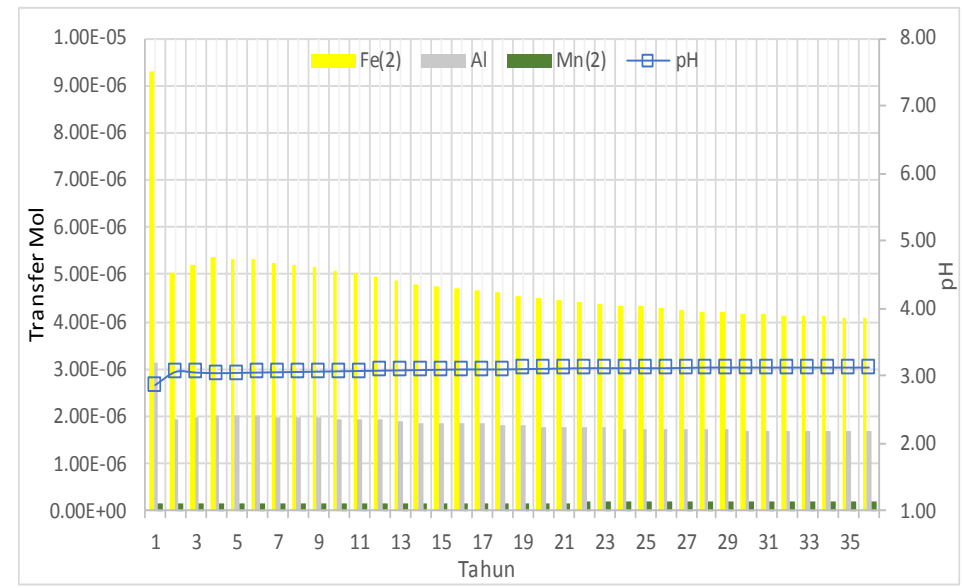

Gambar 10. Grafik Nilai pH, Fe(2), Al, dan Mn(2) pada Skenario Konservatif Awal

\section{iii. Skenario Proporsional}

Skenario proporsional melibatkan semua sampel yang akan mewakili masing-masing luas area berdasarkan litologi dinding pit. Skema pencampuran berdasarkan luas area tersebut juga berdasarkan proporsi dari luas area masing-masing sampel yang mewakili. Apabila setiap tahunnya, air akan bertambah memenuhi pit, maka proporsi untuk luas sampel yang mewakili 
litologi juga akan berkurang. Namun berbeda dengan luas area air hujan yang masuk akan semakin bertambah setiap tahunnya. Sampel S2 tidak akan bereaksi pada tahun ke-15 karena luas area yang sudah tertutup oleh air. Sedangkan sampel S1 akan tertutup pada tahun ke-28. Sampel S3 dan S4 akan terus bereaksi karena litologi sampel berada di atas air yang telah memenuhi pit lake (Gambar $11)$.

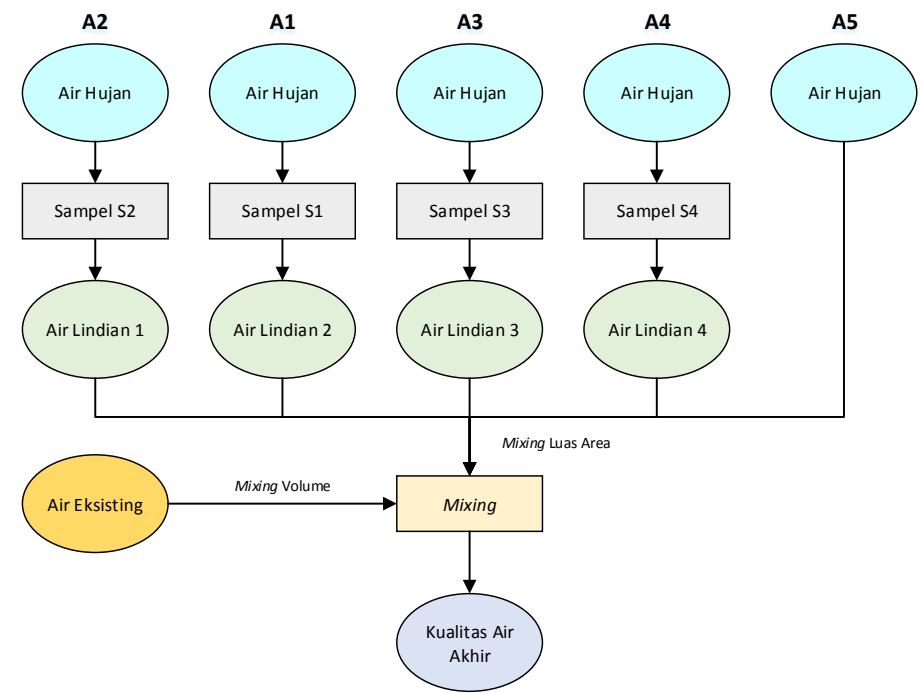

Gambar 11. Skema Pencampuran Skenario Proporsional

Pada skenario proporsional ini nilai $\mathrm{pH}$ mengalami perubahan sejak awal pembentukan dengan nilai 3,24 dan di tahun ke-36 naik menjadi 3,42. Nilai transfer mol $\mathrm{Fe}(2)$ mengalami penurunan dari $5,81.10^{-5}$ di tahun pertama sampai $1,88.10^{-5}$ di tahun ke-36. Nilai transfer mol Al mengalami penurunan dari $2,66.10^{-6}$ di tahun pertama sampai $1,60.10^{-6}$ di tahun ke-36 (Gambar 12).

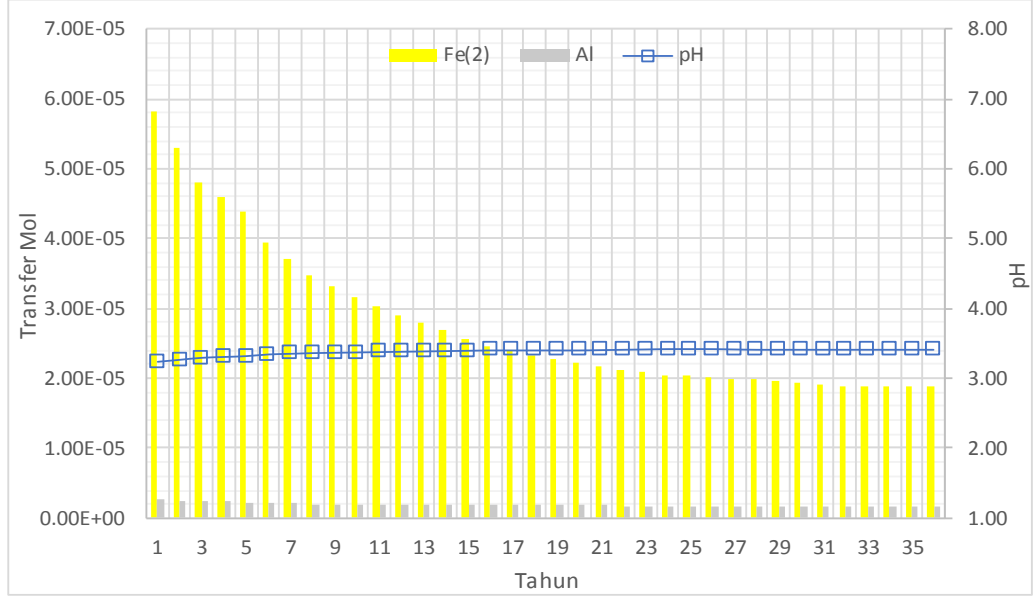

Gambar 12. Grafik Nilai pH, Fe(2) dan Al pada Skenario Proporsional Awal

\section{E. KESIMPULAN}

Kesimpulan yang dapat diambil dari penelitian ini adalah sebagai berikut:

a. Prediksi waktu yang dibutuhkan untuk pengisian air di pit lake dan mencapai kondisi stabil terjadi di tahun ke-36 dengan total volume air $24.000 .000 \mathrm{~m}^{3}$. Sumber air untuk pengisian pit lake hanya dari air hujan langsung yang jatuh ke dalam pit dengan tidak mempertimbangkan luas catchment area di sekitar pit atau lokasi penelitian. 
b. Berdasarkan hasil simulai prediksi kualitas air dengan menggunakan tiga skenario yakni skenario optimis, skenario konservatif dan skenario proporsional, diperoleh prediksi kualitas air pada masing-masing sekenario tersebut terutama untuk nilai $\mathrm{pH}$ di tahun ke-36 adalah skenario optimis sebesar 6,8, skenario konservatif sebesar 3,13 dan skenario proporsional sebesar 3,42.

\section{DAFTAR PUSTAKA}

Gautama, R. S. (2014): Pembentukan, Pengendalian dan Pengelolaan Air Asam Tambang, Penerbit ITB, Bandung.

Castendyk, D.N, Eary, L. E dan Balistrieri, L.S. (2015): Modeling and management of pit lake water chemistry 1: Theroy, Applied Geochemistry, 57, 267-288.

Oldham, C. (2014): Environmental Sampling and Modelling for the Predection of Long-Term Water Quality of Mine Pit lakes. UWA Publishing, Crawley, Western Australia.

Parkhurst, D.L. and Appelo, C.A.J. (1999) User's Guide to PHREEQC (Version 2)-A ComputerProgram for Speciation, Batch-Reaction, One-Dimensional Transport, and Inverse Geochemical Calculations. U.S. Geological Survey, Water Resources Investigations Report $\quad 99-\quad 4259$, Washington DC. 